\title{
Religiusitas dan Penerimaan Diri Pada Penderita Diabetes Mellitus
}

\author{
Hesti Badaria \\ Yulianti Dwi Astuti \\ Universitas Islam Indonesia
}

\begin{abstract}
This current research is aimed at finding a correlation between religiosity and self acceptance among diabetic patients. Data were collected from 30 patients diagnosed with diabetes mellitus. using questionnaire and were analyzed with Pearson product moment correlation. The result indicates that there is a significant correlation between religiosity and self acceptance $(r=.603, p<.05)$. It can be said that $36 \%$ of the variance in Self acceptance among diabetic patients are explained by their religiosity. Practical and future research implication are discussed.
\end{abstract}

Key words: religiosity, self acceptance, diabetes mellitus

\section{Pendahuluan}

B erbagai penelitian dilakukan berkaitan dengan penderita diabetes mellitus (selanjutnya disingkat DM), di antaranya pada pola hidup penderita, seperti diit yang tepat, gerak badan atau olahraga yang tepat, penggunaan obat sampai dengan faktor psikologis para penderita. Salah satu penelitian itu adalah penelitian pada The Journal of American Medical Association yang melaporkan sebuah penemuan hasil studi 21 ribu orang dokter. Penelitian ini menyatakan bahwa dengan berolah raga lima kali seminggu akan menurunkan 42 persen pada kasus penderita DM. Bahkan seminggu sekali saja dapat mencegah kemungkinan orang mendapat serangan DM. (Johnson, 1998)

Bagi beberapa orang, menerima kenyataan bahwa dirinya adalah penderita DM merupakan hal yang menyakitkan dan berlarut-larut. Malangnya, beberapa orang tak pernah mampu untuk menyesuaikan dirinya baik secara emosional maupun fisik, bahkan ada beberapa orang yang menolak dan menyangkal diagnosa dokter. Beberapa penderita yang menolak diagnosa dokter menolak pula dalam menggunakan obat-obatan dan menyuntikkan insulin serta tidak mau merubah pola hidupnya seperti yang dianjurkan oleh dokter. Hal yang seperti ini cukup mengindikasikan rendahnya penerimaan diri pada penderita DM.

Selain hal di atas, hal lain yang mengindikasikan rendahnya penerimaan diri pada penderita adalah rendahnya ketaatan pada penderita dalam memenuhi aturan yang sudah ditetapkan oleh dokter. Hal seperti ini dapat dilihat dari sulitnya para penderita dalam mengontrol gula darahnya. Kerapkali pasien yang datang ke dokter adalah pasien yang gula darahnya sudah tinggi. 
Menerima suatu penyakit bagi seorang penderita tidaklah terjadi dengan begitu saja. Seorang penderita haruslah punya pikiran yang positif terhadap penyakitnya. Pikiran positif adalah suatu pikiran di mana penderita menganggap bahwa penyakitnya bukanlah suatu kutukan, tetapi merupakan implementasi rasa sayang Sang Pencipta kepada dirinya. Penderita juga menjadikan penyakitnya sebagai sandang yang menutupi tubuhnya yang akan mempercantik dirinya. Sehingga timbul suatu keyakinan bahwa dirinya berbeda dengan orang lain. Perbedaan ini adalah perbedaan dalam arti yag positif. Perbedaan dirinya dengan orang lain harus mampu diterima penderita seperti apa adanya. Penderita mampu untuk menerima kodratnya dengan segala kekurangan dan kelemahannya secara tawakal untuk menumbuhkan sikap penerimaan terhadap sesuatu, untuk itu penderita harus mempunyai bekal pengetahuan agama dan suatu keyakinan bahwa di luar dirinya ada suatu ketakutan yang oleh para ahli psikologi agama disebut religious instinct atau naluri keberagamaan (Subandi, 1988).

Sikap keyakinan atau religiusitas ini akan muncul suatu penghayatan akan kehadiran ilahi untuk memberi semangat dalam menempuh kehidupan dan menumbuhkan sikap rela menerima dan ikhlas terhadap apa-apa yang sudah ditentukan oleh sang pencipta. Sikap rela dan ikhlas itu bukanlah sikap yang hanya pasrah tanpa usaha, tetapi harus disertai usaha yang maksimal.

Dengan latar belakang permasalahan tersebut, sangat penting untuk diketahui apakah religiusitas memiliki kaitan dengan sikap penerimaan diri pada penderita DM?

\section{Dasar Teori}

Menurut Calhoun dan Acocella (Wibowo, 1998) penerimaan diri merupakan aset pribadi yang berharga karena mempunyai pengaruh terhadap penyesuaian diri yang dilakukan oleh individu, sehingga sifat-sifat dalam dirinya seimbang dan terintegrasi. Orang-orang yang penerimaan dirinya positif, berarti orang itu mampu memahami dirinya dan menerima kenyataan bahwa dirinya berbeda dengan orang lain. Dalam menerima dirinya sendiri, seseorang harus dapat menyesuaikan diri dengan masyarakat dan kehidupannya. Hal ini sesuai dengan pendapat Hurlock (1994) bahwa tingkat penerimaan diri seseorang akan menentukan tingkat penyesuaian. Penerimaan diri membantu seseorang untuk mewujudkan kemampuan dirinya.

Banyak keadaan (seperti tritmen dokter) yang dialami penderita dan membuat penderita merasa stres dan depresi (Hanson dkk dalam Hadriami dan Martaniah, 2000). Padahal stres dan naiknya tingkat gula darah saling mempengaruhi baik secara langsung maupun tidak langsung. Pendapat ini didukung pula oleh pendapat Rubin dan Peyrot (Hershbach, 1997) yang menyatakan bahwa diabetes dapat menjadi penyebab stres dan pada beberapa kelompok orang dapat menjadi indikasi naiknya gula darah (parahnya penyakit). Selain itu juga bahwa banyak kondisi sakit dan anjuran tritmen yang merupakan sumber stres bagi penderita DM. Berdasarkan wawancara yang dilakukan oleh Martaniah dan Hadriami (2000), diketahui bahwa sebagian besar penderita menyatakan bahwa masalah diet merupakan masalah yang sangat mengganggu sehingga menjadi sumber stres tersendiri bagi penderita.

Adakalanya dalam menghadapi penyakitnya, penderita tidak mampu untuk menerima penyakitnya yang ditandai dengan penyesuaian diri penderita. Banyak respon yang dikeluarkan penderita, diantaranya menyangkal, depresi atau marah-marah, merasa jengkel, menarik diri dari lingkungannya atau merasa putus asa (Johnson, 1998). Respon seperti ini tidak akan berlangsung seterusnya. Lama kelamaan penderita harus menunjukkan bahwa masa penolakannya sudah berakhir dan kenyataan yang ada pada dirinya harus benar-benar 
diterimanya. Dalam hal ini kesadaran dan penerimaan penderita terhadap penyakit DM itu tergantung penderita itu sendiri, selain dukungan dari orang -orang di sekitarnya serta keyakinan penderita itu sendiri akan pertolongan sang pencipta.

Agama menurut Thouless (Darajat, 1973) adalah suatu proses hubungan seorang manusia yang dirasakannya terhadap sesuatu yang diyakininya, bahwa sesuatu itu juga yang diyakininya lebih tinggi dari manusia, hampir senada dengan pendapat Frazer (Darajat, 1973) yang menyatakan bahwa agama adalah pencarian keridhaan atau kekuatan yang lebih tinggi daripada manusia, yaitu kekuasaan yang disangka oleh manusia dapat mengendalikan, menahan atau menekan kelancaran alam dan kehidupan manusia. Agama yang diyakini individu adalah suatu keyakinan terhadap suatu kekuatan yang akan menolong manusia dalam kehidupannya.

Di samping berbagai pendapat ahli diatas, terdapat juga istilah religi (dalam bahasa Inggris religion) dan ad din (dalam bahasa Arab) yang artinya sama yaitu agama. Menurut Anshari (Diana, 1999) walaupun secara etimologisnya memiliki arti yang berbeda namun secara terminologisnya istilah di atas mempunyai inti makna yang sama. Dari uraian di atas dapat diambil pengertian keberagamaan dan pengertian religiusitas (re/igiousity) dapat disamakan.

Untuk mengenal agama, manusia membutuhkan naluri untuk beragama. Menurut Subandi (1988), ahli-ahli psikologi menyebut naluri keberagamaan atau religious instinc yaitu suatu naluri atau insting untuk meyakini dan mengadakan suatu penyembahan terhadap suatu kekuatan yang ada di luar dirinya. Hampir senada dengan pendapat Jung (dalam Fromm, 1988) yang menyatakan bahwa hakekat pengalaman beragama adalah sikap submisif (berserah diri) terhadap kekuatan yang lebih tinggi daripada dirinya sendiri. Pendapat-pendapat diatas searah dengan pendapat yang dirumuskan dalam kamus Oxford (Fromm, 1988). Menurutnya agama merupakan pengenalan manusia akan kekuatan gaib yang lebih tinggi yang akan mengontrol tujuan hidup manusia atau sesuatu hal yang dijuluki sebagai pengabdian, pemujaan dan persembahan, yang unsur hakiki dari agama dan pengalaman religiusnya adalah penyerahan diri kepada kekuatan di atas manusia.

Banyak para ahli psikologi yang mengungkapkan tentang dimensi religiusitas. $\mathrm{Di}$ antaranya Glock dan Stark (dalam Ancok \& Suroso, 1994; Astuti, 1999; Rakhmat, 2003) yang mengungkapkan beberapa aspek religiusitas. Aspek-aspek itu adalah: 1) Religious belief yaitu suatu tingkatan sampai sejauh mana individu menerima hal-hal yang dogmatik dalam agama yang dianutnya. 2) Religious practice yaitu suatu tingkatan dimana individu dipertanyakan seberapa jauh individu mengerjakan kewajiban-kewajiban ritual yang telah ditetapkan oleh agama. 3 ) Religious feeling yaitu suatu pengalaman beragama, perasaan-perasaan, persepsi dan sensasi-sensasi yang dialami individu ketika berkomunikasi dengan sang pencipta. 4) Religious knowledge yaitu sisi pengetahuan individu terhadap agamanya terutama aktifitas dalam mencari pengetahuan itu sendiri. 5) Religious effect yaitu konsekuensi individu terhadap ajaran agamanya dan terwujud dalam perilakunya dengan sesama manusia.

Agama memegang peranan penting dalam kehidupan manusia. Manusia membutuhkan agama untuk memenuhi kebutuhan rohani serta mendapat ketenangan dalam hidupnya. Menurut Rakhmat dan Ramayulis (1987), agama berpengaruh dalam jiwa, sehingga agama dapat mengubah seseorang yang hidup tanpa tujuan dan bergelimang dosa secara serta merta atau berproses menjadi seorang manusia yang hidup dengan benar. Pengaruh agama dalam diri seseorang akan terlihat dalam perilaku dan kehidupannya sehari-hari. Individu yang benar-benar membutuhkan agama akan menganggap agama adalah kebutuhan yang mau tidak mau memang dibutuhkan atau alamiah (fitrah). 
Artinya agama menjadi kebutuhan yang berasal dari lubuk jiwanya (hatinya), sesuai dengan pendapat Muthahhari (1992) yang menyatakan bahwa agama adalah kebutuhan fitrah manusia. Sehingga dapat dikatakan bahwa manusia mempunyi rasa butuh atau tergantung terhadap agama.

Rasa ketergantungan dan tidak berdaya akan menimbulkan suatu perasaan aman. Sesuai dengan pendapat Fromm (1988) yang menyatakan dengan sikap berserah diri kepada Sang Pencipta dengan sepenuhnya dengan cara menanggalkan kebebasan dan integritas dirinya sebagai seorang individu serta dengan rela mengikuti aturan-aturan yang telah ditetapkan akan membuat individu memperoleh perasaan terlindungi oleh suatu kekuatan yang mengagumkan yang menjadikan dirinya bagian dari kekuatan itu yaitu kekuasaan Tuhan yang maha esa. Rasa ketergantungan, ketidak berdayaan dan keyakinan terhadap kekuatan sang pencipta akan menimbulkan sikap optimis terhadap segala sesuatu.

Bagi seorang penderita dibetes mellitus sikap optimis sangatlah dibutuhkan berkaitan dengan penyesuaian diri dengan pola hidupnya. Seorang penderita DM merupakan seseorang yang menderita suatu penyakit yang akan terus menerus diidap seumur hidupnya. Oleh karena itu dibutuhkan penyesuaian dengan pola hidupnya selama seumur hidupnya pula.

Penyesuaian pola hidup yang mencakup perubahan pola makan, olah raga, dan minum obat atau harus menyuntikkan insulin bagi penderita tipe satu setiap harinya dan seumur hidupnya. Tidak semua penderita mampu dan mau melakukan perubahan pada pola hidupnya. Bagi penderita DM apalagi yang masih muda, melakukan perubahan pola hidup seperti yang sudah ditetapkan sangatlah susah bahkan bisa jadi hal itu menimbulkan suatu keputusasan. Rasa putus asa itu timbul jika tanpa disertai oleh keyakinan agama dari penderita itu sendiri. Menurut Rakhmat dan Ramayulis (1987), keyakinan keagamaan akan menciptakan dalam diri manusia suatu kekuatan untuk bertahan dan merubah sesuatu yang pahit menjadi yang manis. Keyakinan itu berupa keyakinan keagamaan atau keyakinan bahwa ada suatu kekuatan yang mengatur segalanya. Hal itu serupa dengan yang diungkapkan oleh Darajat (Astuti, 1999) yang mengungkapkan bahwa bagi orang yang mempunyai keyakinan agama, kesukaran hidup merupakan bagian dari cobaan tuhan kepada hambanya yang beriman. Cobaan atau ancaman tidak dipandang negatif tetapi sebaliknya di antara kesukaran itu ada suatu harapan dan kemudahan. Selain itu, individu yang mempunyai keyakinan terhadap agama akan memandang penderitaan itu sebagai hal yang wajar sehingga hal itupun akan diterima dengan perilaku dan sikap penyerahan diri yang wajar pula.

Sikap penyerahan diri terhadap sang pencipta bukanlah suatu sikap penyerahan diri yang pasrah tanpa usaha, tetapi harus disertai dengan usaha yang maksimal. Sikap pasrah dan penyerahan diri terhadap sang pencipta haruslah suatu sikap yang positif dan sinkron dengan batinnya dan tampak pada perilakunya. Dalam berperilaku, individu yang memiliki religiusitas akan mengamalkan ajaran agamanya dengan kecendrungan untuk berpasrah diri terhadap nasib yang mereka terima, artinya individu yang memiliki religiusitas yang akan mempunyai sikap penerimaan diri terhadap apa yang ada pada dirinya. Seorang penderita DM yang memiliki tingkat religiusitas yang tinggi tentunya akan menerima penyakitnya. Dengan didukung sikap penyerahan diri, penderita akan memiliki sikap pasrah. Menurut Rakhmat dan Ramayulis (1987) individu yang mempunyai religiusitas akan mengamalkan ajaran agama dan cenderung pasrah terhadap nasib, selain itu individu juga mempunyai rasa taat yang tinggi sehingga individu mempunyai keyakinan bahwa penderitaan dan kenikmatan yang mereka terima sepenuhnya berasal dari sang pencipta. Rasa dan keyakinan seperti inilah 
yang menyebabkan individu tahan dalam menerima semua penderitaan.

Bagi seorang penderita DM menderita penyakit ini merupakan salah satu penderitaan jasmani atau fisik. Menurut Freud (Dister, 1983) kesusahan jasmani atau fisik seperti sakit akan terasa ringan dan teratasi bila orang memeluk agama atau punya keyakinan tentang agama. Dengan demikian dapat dikatakan agama dapat menjadi pegangan dalam menghadapi kesusahan hidupnya. Hal senada diungkapkan oleh Najati (1984) bahwa faktor yang dapat membantu membangunkan atau mem-bangkitkan religius pada manusia adalah apabila seorang manusia berada dalam keadaan bahaya atau kesusahan, maka tidak ada jalan lain baginya kecuali berlindung dan meminta pertolongan kepada sang pencipta. Selanjutnya dijelaskan bahwa hal seperti itu memang sudah menjadi fitrah manusia seperti yang diungkapkan dalam $\mathrm{Al}$ Quran surat Yunus ayat 22 dan surat Al An'am ayat 63 yang dapat disimpulkan bahwa jika manusia mulai mengalami kesusahan, musibah atau bahaya, mereka dengan suara merendah memohon agar Allah SWT menyelamatkan mereka dan menolong mereka. Bila dalam meminta kepada Sang Pencipta disertai dengan keyakinan, rasa percaya dan kepasrahan yang tulus, maka akan timbul keyakinan bahwa apa yang dialami individu adalah sesuatu yang memang ditakdirkan kepadanya dan lama kelamaan keyakinan itu akan menimbulkan suatu sikap diri untuk menerima segala ketentuan sang pencipta terutama pada penyakit yang dideritanya.

\section{Hipotesis}

Berdasarkan uraian-uraian diatas, maka hipotesis yang diajukan dalam penelitian ini adalah ada hubungan positif antara religiusitas dan penerimaan diri pada penderita DM. Semakin tinggi religiusitas pada penderita DM maka penerimaan diri pada penderita DM juga semakin tinggi dan sebaliknya semakin rendah religiusitas pada penderita DM maka penerimaan diri pada penderita DM juga semakin rendah.

\section{Metode Penelitian}

Variabel yang digunakan dalam penelitian ini adalah:

\section{Variabel tergantung : Penerimaan diri \\ 2. Variabel bebas : Religiusitas}

Penerimaan diri adalah sikap individu untuk menerima kenyataan pada dirinya berupa kekurangan atau kelebihannya, serta mampu mengaktualisasikan kehidupannya di masyarakat dan berusaha untuk melakukan hal-hal yang terbaik untuk dirinya, sebagaimana yang diungkapkan dalam skala penerimaan diri, yang mengacu pada aspek yang diungkapkan oleh Shereer (Cronbach, 1963). Aspek itu adalah: mempunyai keyakinan akan kemampuan untuk menghadapi kehidupannya, menganggap dirinya berharga sebagai manusia dan sederajat dengan orang lain, berani memikul tanggung jawab terhadap perilakunya, menerima pujian dan celaan secara objektif, menyadari keterbatasannya, tidak menyalahkan kekurangannya serta tidak mengingkari kelebihannya, tidak ada rasa malu terhadap keadaan dirinya, serta tidak ada anggapan aneh terhadap dirinya sendiri atau ada harapan untuk diterima orang lain. Pengukuran terhadap variabel ini dilakukan dengan menggunakan skala. Skala Penerimaan Diri ini disusun sendiri oleh penulis, untuk mengungkap tinggi rendahnya penerimaan individu terhadap penyakit yang dideritanya.

Religiusitas adalah suatu sikap penyerahan diri kepada suatu kekuatan yang ada di luar dirinya yang diwujudkan dalam aktivitas dan perilaku individu sehari-hari, yang diungkap dengan aspek yang dikemukakan oleh Glock dan Stark (Ancok \& Suroso, 1994; Astuti, 1999; Rakhmat, 2003). Aspek-aspek itu ialah: religious belief, religious practise, religious feeling, religious knowledge, dan reli- 
gious effect. Religiusitas dapat diketahui dari skor yang diperoleh subjek setelah mengisi skala religiusitas. Semakin tinggi skor yang diperoleh maka semakin tinggi pula religiusitas pada penderita. Semakin rendah skor yang diperoleh maka religiusitas pada penderita semakin rendah. Skala religiusitas ini disusun sendiri oleh peneliti.

Subjek yang terlibat dalam penelitian ini adalah penderita diabetes mellitus (minimal 1 tahun) yang berdomisili di daerah Yogyakarta.

Untuk menguji adanya hubungan antara religiusitas dan penerimaan diri terhadap penyakit DM digunakan tekhnik product moment dari Karl Pearson. perhitungan statistik dan pengujian hipotesis dilakukan dengan menggunakan jasa komputer seri program statistik SPSS 10,0 for windows.

\section{Hasil Penelitian}

Dari hasil analisis diperoleh besarnya koefisien korelasi antara variabel penerimaan diri dengan religiusitas adalah $0,603(p=$ 0,000 atau $p<0,01$ ). Hal ini menunjukkan bahwa ada korelasi yang sangat signifikan antara variabel religiusitas dan penerimaan diri pada penderita DM. Sehingga hipotesis yang diajukan dapat diterima.

Hasil lain yang diperoleh adalah nilai koefisien determinasi ( $R$ Squared) sebesar 0,364 yang berarti bahwa religiusitas memberikan sumbangan efektif sebesar 36,4 $\%$ terhadap penerimaan diri pada penderita DM.

Hasil penelitian di atas ditambah dengan analisis mengenai hubungan antara aspekaspek religiusitas dengan penerimaan diri. Hasil analisis itu adalah sebagai berikut:

a. Dari hasil analisis diperoleh besarnya koefisien korelasi antara variabel penerimaan diri dengan variabel religiusitas aspek religious belief adalah $0,231 \quad(p=$ 0.220 atau $p>0,05$ ). Dapat disimpulkan bahwa tidak ada korelasi yang signifikan antara variabel religiusitas aspek religious belief dengan variabel penerimaan diri.

b. Hasil analisis koefisien korelasi antara variabel penerimaan diri dan variabel religiusitas aspek religious practise menunjukkan hasil sebesar $0,728(p=$ 0,000 atau $p<0,01$ ). Hal ini menunjukkan bahwa ada korelasi yang signifikan antara variabel religiusitas aspek religious practise dengan variabel penerimaan diri. Sumbangan efektif religious practise adalah sebesar $53,1 \%$.

c. Hasil analisis koefisien korelasi antara variabel penerimaan diri dan variabel religiusitas aspek religious feeling menunjukkan hasil sebesar $0,638(p=0,000$ atau $p<0,01$ ). Hal ini menunjukkan bahwa ada korelasi yang signifikan antara variabel religiusitas aspek religious feeling dengan variabel penerimaan diri. Sumbangan efektif religious feeling adalah sebesar 40,7 $\%$.

d. Hasil analisis koefisien korelasi antara variabel penerimaan diri dan variabel religiusitas aspek religious effect menunjukkan hasil sebesar $0,309(p=0,096$ atau $p>0,05$ ). Hal ini menunjukkan tidak ada korelasi antar variabel religiusitas aspek religious effect dengan variabel penerimaan diri.

e. Hasil analisis koefisien korelasi antara variabel religious knowledge dan variabel penerimaan diri menunjukkan hasil sebesar $0,036(p=0,852$ atau $p>$ 0,05 ). Ini menunjukkan tidak ada korelasi yang signifikan antara variabel religious knowledge dengan variabel penerimaan diri.

\section{Pembahasan}

Dalam kehidupan setiap manusia pasti mengalami kesusahan dan kesenangan. Begitu juga yang dihadapi oleh para penderita diabetes mellitus. Apa yang dialami oleh para penderita DM adalah suatu kesusahan atau musibah sekaligus suatu rahmat atau 
kesenangan, tergantung dari individu yang menerima peyakitnya. Bagi individu yang mempunyai sikap religiusitas yang tinggi, akan menganggap penyakit yang dideritanya bukanlah suatu musibah atu kesusahan tapi ia menganggap hal itu sebagai rahmat yang akan menyenangkan kehidupannya. Bagi penderita diabetes yang mempunyai sikap religiusitas yang tinggi akan mempercayai dan meyakini apa yang dialaminya sudah menjadi takdir dari yang maha kuasa. Hal ini sesuai dengan pendapat Darajat (Astuti 1999) yang menyatakan bahwa bagi orang yang beragama kesukaran dalam hidup merupakan bagian dari cobaan Tuhan kepada hamba-Nya yang beriman. Individu akan menerima segala cobaan dan melihatnya sebagi sesuatu yang wajar. Orang yang mempunyai sikap religius juga akan memandang cobaan itu sebagai suatu rahmat bagi dirinya. Individu juga akan menganggap bahwa mereka adalah orang-orang pilihan yang memang pantas untuk diuji. Boleh jadi apa yang ada dan terjadi pada individu tidak disukai tapi itulah yang terbaik bagi individu. Hal ini sesuai dengan Al Qur'an surat Al Anbiya ayat 35, yang artinya "Kami akan menguji kalian dengan keburukan dan kebaikan sebagi cobaan (yang sebenarbenarnya). Dan hanya kepada kamilah kalian kembali." (QS AI Anbiya:35)

Hasil penelitian yang menunjukkan bahwa sumbangan efektif religiusitas terhadap penerimaan diri seseorang sebesar $36,4 \%$, cukup mengindikasikan bahwa faktor religiusitas memberi sumbangan yang cukup besar bagi penerimaan diri pada penderita DM, di mana para penderita sangat sulit untk menerima suatu kenyataan bahwa dirinya adalah seorang penderita DM. Religiusitas akan memberikan rasa optimis bagi penderita diabetes untuk menjalani kehidupannya. Rasa optimis inilah yang akan membantu penderita untuk menerima keadaan dirinya. Pandangan di atas sesuai dengan pendapat Seligman (Astuti,1999), bahwa agama merupakan harapan bagi orang yang mempercayainya. Individu yang mempunyai sikap religiusitas akan mempercayai apapun yang dialaminya sudah ada yang mengatur, sehingga musibah seberat apapun akan diterimanya dengan tulus, tanpa ada rasa putus asa, marah ataupun rasa pesimis. Sehingga segala sesuatu akan dipandangnya dengan rasa optimis.

Dari hasil penelitian terlihat bahwa sumbangan yang paling besar terletak pada religious practice (praktek agama /ibadah) yaitu sebesar $53,1 \%$ dan religios felling (perasaan/pengalaman agama) dengan sumbangan efektif 40,7\%. Hal ini karena bagi seorang penderita DM, ketenangan dalam pikiran atau menjauhkan diri dari stres sangat dibutuhkan, karena stres dapat menaikkan tingkat gula darah. Bagi seorang penderita diabetes bila sedang mengalami suatu masalah yang berat, komunikasi dengan sang pencipta sangat dibutuhkan. Karena dengan berkomunikasi inilah para penderita biasanya akan merasa puas dan merasa masalah mereka selesai atau walaupun masalahnya tidak terpecahkan individu sudah merasa tenang karena sudah sepenuhnya percaya akan bantuan dari sang pencipta dan menyerahkan (bertawakal) kepada sang pencipta Allah SWT. Rasa tenang itu akan membuat pasien jauh dari rasa stres, yang dapat mencegah naiknya gula darah (memperparah penyakit). Sedangkan pada aspek religious feeling atau perasaan dan pengalaman ritual akan membuat individu yang sakit merasa yakin akan kehadiran sang pencipta yang itu juga akan membuat penderita diabetes merasa tenang. Selain mendapatkan perasan tenang, individu yang religius juga akan mendapatkan perasaan aman, sesuai dengan Al Qur'an surat Ar-Ra'd ayat 28 yang berbunyi : "(yaitu) orang-orang yang beriman dan hati mereka menjadi tentram dengan mengingat Allah . ingatlah, hanya dengan mengingat Allahlah hati menjadi tentram" (QSAr Ra'd:28). Hal ini menunjukkan bahwa perasaan dan pengalaman beragama sangat diperlukan oleh individu untuk menerima penyakit yang diidapnya. 
DM adalah suatu penyakit yang dari dulu tidak bisa disembuhkan dan hanya bisa dikontrol, sehingga sikap optimisme yang timbul dari penderita bukanlah suatu sikap pengharapan bahwa penyakit itu akan hilang begitu saja dari dirinya atau ia akan sembuh secara total, melainkan sikap optimis untuk berbaik sangka kepada Sang Pencipta. Sikap berbaik sangka itu akan membantu para penderita untuk mengurangi rasa stres akibat dari penyakit yang dialami oleh penderita. Biasanya stres yang dialami penderita adalah stres yang dikarenakan keharusan untuk mngubah pola hidupnya serta stres karena ketakutan akan menghadapi penyakitnya. Sikap berbaik sangka kepada sang pencipta akan menimbulkan suatu pemikiran dimana penderita berpikir bahwa apa yang terjadi pada dirinya pasti ada hikmahnya. Dengan berpikir seperti ini penderita akan jauh dari rasa stres.

Sikap religius yang dimiliki oleh penderita dapat membantu penderita mengatasi pikiran buruk yang ada pada penderita. Pikiran buruk itu dapat menyebabkan penderita merasa stres sehingga tingkat gula darah tidak terkontrol. Sikap religius akan membuat penderita merasa tenang, jauh dari rasa takut ataupun depresi, sehingga religiusitas dapat membantu para penderita DM menerima keadaannya dan berusaha untuk mengikuti segala sesuatu yang telah ditetapkan oleh dokter sesuai dengan aturan untuk para penderita diabetes.

Sikap pengharapan atas rahmat Allah 'Azza wa jalia akan muncul pada orang-orang yang mempunyai perilaku religius. Sikap pengharapan itu akan tampak pada perilaku para penderita DM. Seorang penderita yang mempunyai sikap pengharapan ini akan terlihat dari perilakunya dalam mentaati trimen yang telah ditetapkan oleh dokter termasuk mengubah pola hidup serta kedisiplinan untuk minum obat atau menyuntikkan insulinnya. Sikap pengharapan itu haruslah suatu sikap yang murni memang karena Allah. Artinya obat dan tritmen yang ditetapkan oleh dokter hanyalah sebagai perantara saja, sedangkan kesembuhan itu akan terjadi karena kekuasaan Allah. Sikap yang seperti ini akan benar-benar membangkitkan optimisme pada seorang penderita DM.

Sikap penerimaan diri ini dapat memperkecil usaha seseorang untuk memikirkan hal-hal yang dapat menimbulkan stres (Hadriami dan Martaniah, 2000). Bila penerimaan diri seorang penderita DM tinggi, maka bagi dirinya penyakit yang dideritanya bukanlah suatu masalah yang dapat mengganggu kehidupannya. Seorang penderita DM dengan mudah akan menerima penyakitnya dan menjalankan segala tritmen dokter dengan tanpa beban, bahkan mampu hidup dalam masyarakat tanpa perlu memikirkan perbedaan dirinya dengan orang lain dan penyakitnya.

Kelemahan dari penelitian ini adalah antara lain angket yang tidak langsung diisi oleh subjek pada saat peneliti menyerahkan skala. Hal ini terjadi karena pernyatanpernyatan yang harus dijawab oleh subjek sangat banyak, sehingga subjek lebih suka mengerjakan di rumah. Padahal yang seperti itu bisa saja menimbulkan bias karena bisa jadi yang mengisi angket bukan yang bersangkutan, tetapi orang lain. Pernyatanpernyataan dalam skala itu dapat menimbulkan interpretasi yang berbeda dari tiap subjek, sehingga hal ini dapat mempengaruhi jawaban yang akan diberikan.

\section{Kesimpulan}

Kesimpulan yang dapat ditarik dari penelitian ini adalah bahwa ada hubungan yang sangat signifikan antara religiusitas dengan penerimaan diri pada penderita DM. Semakin tinggi religiusitas pada penderita DM semakin tinggi pula penerimaan diri., dan sebaliknya semakin rendah religiusitas semakin rendah pula penerimaan diri. 


\section{Saran}

Penelitian yang dilakukan oleh peneliti ini masih banyak terdapat berbagai kekurangan yang tidak dapat dikontrol oleh peneliti. Sehubungan dengan hasil penelitian dan kesimpulan, peneliti mencoba untuk memberikan beberapa saran. Pertama, hendaknya pasien lebih mempunyai sikap yang religius dalam menghadapi penyakitnya. Pasien juga harus punya keyakinan bahwa penyakit yang dideritanya sudah merupakan kehendakAllah, dan itu pasti ada hikmahnya. Dalam meyakini hal itu pasien hendaknya tidak hanya pasrah saja, tetapi harus ada usaha untuk mengontrol dan mengobati penyakit yang diderita misalnya dengan secara teratur mengontrol diri ke dokter, mengubah pola hidup yang telah ditentukan, tidak hanya secara fisik, tapi juga secara psikis dengan cara menghindari pikiran yang buruk dan selalu berpikiran positif terutama kepada sang pencipta.

Kedua, dokter hendaknya tidak hanya melayani pengobatan pasien saja, tetapi juga dapat memberikan nasehat-nasehat yang bersifat spiritual yang dapat meyakini penderita untuk menerima penyakitnya. Selain itu para dokter seharusnya dapat menjalin hubungan yang baik dengan para penderita DM, karena hubungan dokter dengan penderita DM adalah hubungan jangka panjang, dimana seumur hidupnya pasien akan terus mengunjungi dan membutuhkan petunjuk-petunjuk dokternya.

Ketiga, hendaklah para peneliti memperhatikan jumlah aitem-aitem yang ada, karena banyak kondisi pasien yang tidak cukup mampu untuk menjawab pertanyaan. Selain itu perlu juga dicermati metode dan proses pengambilan data. Penelitian ini hanya melihat hubungan antara religiusitas dan penerimaan diri, sehingga penelitian selanjutnya diharapkan dapat melihat faktorfaktor lain seperti dukungan sosial, tingkat pendidikan, faktor usia, strategi koping, dan jenis kelamin.

\section{Daftar Pustaka}

Ancok, D. \& Suroso, F.N. 1994. Psikologi Islami: Solusi Islam atas Problemproblem Psikologi. Yogyakarta: Pustaka Pelajar.

Astuti, Y.D. 1999. Hubungan antara Religiusitas dan Gaya Penjelasan. Jurnal Psikologika, Tahun IV, No. 8, hal. 39-52.

Cronbach, L.J. 1963. Educational Psychology. New York: Harcourt, Brace and World, Inc.

Diana, R. 1999. Hubungan Antara Religiusitas dan Kreatifitas Siswa Sekolah Menengah Umum. Jurnal Psiko-logika. Tahun IV, No. 6, hal. 525.

Dister, N. S. 1983. Pengalaman dan Motivasi Beragama, Pengantar Psikologi Agama. Jakarta. Lappenas.

Darajat, Z. 1973. IImu Jwa Agama. Jakarta: Bulan Bintang.

Fromm, E. 1988. Psikoanalisa dan Agama. Surabaya : Bina llmu.

Hadriami,E dan Martaniah, S.M. 2000. Peran Persepsi Keseriusan Sakit dan Koping Pada Penyesuaian Psikologis Penderita Diabetes Melitus. Jurnal Psikodimensia. Semarang: UNIKA Soegiyopranoto.

Hersbach, P. 1997. Psyichometric Properties Of the Questionnaire on Stress in Patients With Diabetes - Revised (QSD-R). Health Psychology Journal Vol 16, No 2, 171-174.

Hurlock, E.B. 1994. Psikologi Perkembangan. Suatu Pendekatan Sepanjang Rentang Kehidupan. Edisi 
Kelima. Jakarta: Erlangga.

Rakhmat dan Ramayulis. 1987. Pengantar IImu jiwa Agama. Jakarta: Kalam Muha.

Johnson, M. 1998. Diabetes: Terapi dan Pencegahannya. Bandung: Indonesia Publishing House.

Muthahhari, M. 1992. Perspektif Al Quran Tentang Manusia dan Agama. Bandung: Mizan.
Najati, M. 'U. 1984. Jiwa Manusia: Dalam Sorotan Al-Qur'an. Jakarta: Cendekia.

Subandi, 1988. Hubungan Antara Religiusitas dan Kecemasan. Laporan Penelitian (Tidak Diterbitkan). Yogyakarta: Fakultas Psikologi UGM.

Wibowo,G.H. 1998. Hubungan Penerimaan Diri dan Persepsi Penerimaan Masyarakat Dengan Kepercayaan Diri Pada Pria Homo Sexsual. Skripsi (Tidak Diterbitkan). Yoyakarta: Fakultas Psikologi UGM. 